\title{
In Vitro Studies on the Mechanism of ACTH Secretion
}

\author{
Hiroshi TANIGUGHI \\ The Second Department of Internal Medicine, Kobe University School of Medicine, \\ Kobe, Japan (Director : Professor Shozo Tsuji, M.D.)
}

It has been a well-known fact that ACTH is released from the adenohypophysis in the case of subjection of an animal to stress, but it is not yet clearly understood whether and how the synthesis in the pituitary gland is related to the release of ACTH under the effect of acute stress. The author has attempted to clarify this problem using in vitro investigation of ACTH release from incubated rat anterior pituitary gland. The pattern of ACTH release from the rat anterior pituitary gland observed with the standard incubation technique using $\mathrm{KRBG}^{*}$ as incubation medium which was named by the author arbitrarily as "spontaneous ACTH release". The response of this pattern to lysine-8vasopressin was studied under various conditions.

\section{Methods}

Female rats of Wistar strain, weighing 120-150 gm, were used as pituitary donors. After removal of pituitary gland, each anterior lobe of pituitary gland was hemisected and placed in a flask containing $2 \mathrm{ml}$ of KRBG. Four pituitary halves supplied by four different rats were placed in one of each pair of flasks, one containing the agents to be tested and the other being used as a control. All flasks were incubated in a metabolic incubator under atmospheric conditions of $95 \%$ of oxygen and $5 \%$ of carbon dioxide at $37^{\circ} \mathrm{C}$. Every 30 minutes the incubation medium was replaced with an equal volume of fresh medium. Incubation was thus continued for several hours. The ACTH activity released in the medium was determined by the in vitro method of ACTH bioassay described by Yasui (Foria Endocr. Jap., 41: 643, 1965). After the final incubation the adenohypophyseal RNA** and DNA*** contents were determined by the method of Schmidt, Thannhauser and Schneider.

The results are summarized as follows:

(I) Spontaneous ACTH release was gradually reduced for 2 hours in the course of incubation, showing the minimum value at this point, and was thereafter demonstrable without cessation during the course of a 5-hour experiment after the onset of incubation, although it was a small amount. The RNA / DNA ratio in the adenohypophysis showed no remarkable change during the whole course of experiment.

free medium.

*Designation of Krebs-Ringer bicarbonate solution containing $200 \mathrm{mg}$ glucose/100 ml.

**Designation of ribonucleic acid.

***Designation of desoxyribonucleic acid. 
(II) Effect of agents added to the medium on spontaneous ACTH release.

(1) The same pattern of ACTH release as in KRBG medium was shown in glucose-

(2) Addition of $10 \mathrm{ug}$ of actinomycin $\mathrm{D}$ in the first incubation medium depressed the release of ACTH in the medium, but after the exchange of medium the release pattern returned to the basal level as in spontaneous ACTH release.

(3) Addition of $50 \mathrm{ug}$ of puromycin in the first medium induced almost no change in the basal pattern for the first 2 hours. The release of ACTH was, however, depressed later in the course.

(4) $60 \mathrm{mU}$ of lysine-8-vasopressin added to the medium 1, 2 or 3 hours after the commencement of incubation caused significant ACTH release in the medium containing the agent at every time point. Thereafter the relaese pattern returned to the basal level.

(5) Based upon the above-mentioned results, it is suggested that ACTH in the adenohypophysis consists of the readily releasable pool of ACTH and the inactive ACTH pool. These pools are likely to possess a sufficient reserve ability, enough to release AGTH during one and a half hours according to the present study. The plausible explanation of this phenomenon can be drawn from the possible existence of equilibrium between the ACTH content of incubation medium and the ACTH release from the adenohypophysis as in the case of the equilibrium between the steriod content of medium and the steroid release from adrenocortical slices. Following this concept, the equilibration of ACTH content between the incubation medium and the adenohypophysis should be deranged by the addition of lysine-8-vasopressin, which causes ACTH release, resulting in reduction of the readily releasable pool of ACTH and inducing the mobilization of ACTH from the inactive ACTH pool to supplement the former pool. The changes in the ACTH generating system seem to be induced in this way. As soon as the equilibrium of ACTH content between the medium and the readily releasable pool is established, the series of this ACTH generating system gradually enters into the equilibration, thus resulting in a uniform rate of synthesis and release of ACTH.

(III) ACTH releasing action of lysine-8-vasopressin in vitro.

(1) The anterior pituitary gland responsded sufficiently to $60 \mathrm{mU}$ of lysine-8-vasopressin after a preincubation period for $0.5,1.5$ or 2.5 hours.

(2) ACTH activity appeared immediately in 5 minutes and showed no further elevation in the medium after 30 or 120 minutes' period. The response of the adenohypophysis to $60 \mathrm{mU}$ of lysine-8-vasopressin was found not in the incubation studies of $5 \mathrm{~min}$ utes, but in 30 minutes. The responses was slightly more prominent in the experiments of 120 minutes duration than in those of 30 minutes duration.

(3) The response of the anterior pituitary gland to $60 \mathrm{mU}$ of lysine-8-vasopressin was remarkable after the preincubation with $10 \mathrm{ug}$ of actinomycin $\mathrm{D}$ or $50 \mathrm{ug}$ of puromycin.

(4) The above-mentioned results seem to indicate that lysine-8-vasopressin acceler- 
ates the transformation of ACTH from the inactive ACTH pool to the readily releasable pool. Thus, an increase of the readily releasable pool inevitably leads to the release of ACTH. Another possible explanation of the effect of lysine-8-vasopressin can be sought in the acceleration of the permeability of membrane of ACTH producing cells. These actions of lysine-8-vasopressin seem unlikely to have any direct relations with protein synthesis in the anterior pituitary gland. It is, therefore, considered that the release of ACTH is caused under acute stress before the synthesis of ACTH in the adenohypophysis takes place.

(See pp. 1066 1080) 


\title{
ACTH 分泌機序に関する実験的研究
}

\author{
神戸大学医学部第二内科学教室 (指導 辻 异三教授)
}

谷口洋

（昭和45年 7 月 1 日受付）

\begin{abstract}
下垂体内での AGTH の存在形式, 更にはその分泌機序の解明の為, in vitro 連続 incubation 法 を用い，ラット下垂体前葉組織片からの spontaneous AGTH release の pattern 及び各種薬物のそ の pattern に及ぼす影響と stressor としての Lysine-8-Vasopressin に対する反応性との二面からの 解析を行なつた結果, 下垂体前葉内に於て ACTH は readily releasable pool とその前段階の inactive AGTH pool の型で存在し, Lysine-8-Vasopressin は後者から前者の pool への変換を促進し, 一部には細胞膜の透過性も元進することにより ACTH の放出を来たし, medium と readily releasable pool との間の平衡の成立と共に ACTH の生成, 放出反応が一定となると解された. 又急激な刺 激下では蛋白合成更には AGTH 合成よりも先ず AGTH の放出が起こると想定された.
\end{abstract}

\section{1 緒言}

生体が特殊な外部，或は内部環境におかれた時，その㻴境の変化に適応して下垂体から AGTH の放出が

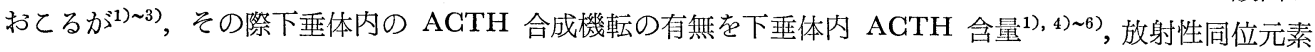
で標識したアミノ酸の下垂体内 $\mathrm{ACTH}^{7)}$ ９)，又は蛋白へ ${ }^{8), 18)}$ のとりてみ，下垂体内 RNA, DNA の変動等 10) 15)を通じて観察した研究が数多く報告されている.しかし未だその詳細な機序に関しては不明な点が多く 残されている. ての AGTH 合成, 分泌機序の研究手段として, 我々は in vivo による方法と in vitro に よる方法とを利用している，in vivo による方法は，中枢神経系一視床下部一下垂体前葉一副腎皮質という 連続性のある系統の中で下垂体 AGTH 合成，分泌機能を出来るだけ分離して純粋て観察しようとするもの であるが，中枢よりの影響と副腎 Corticoid の feedback を受けるてとは避け難い．てれに対して in vitro による方法ではそれらの連続性を切断して各藏器レベル, 即ちての場合では下垂体前葉, 或は細胞レベル, 細胞下レベル等での反応性を検討するととが出来る. 従つて薬物のある臟器への直接作用, 或は大る藏器の 反応の自律性を研究する場合には in vitro による方法は極めて有用である.

著者はラット下垂体の in vitro 連続 incubation 法を用いて，下垂体レベルでの spontaneous ACTH release のパターン及びそれに影響を及ぼす各種薬物による変化と, stressor としての Lysine-8-Vasopressin に対する反応性との二面からの解析的研究を行ない，下垂体内での AGTH の存在形式，更にそれを通して の分泌機序の検討を試みたので以下に報告する.

\section{II 実験材料及び方法}

実験開始 1 週間前より室温約 $23^{\circ} \mathrm{C} の$ 飼育室にてオリエンタル 固形飼料で飼育した体重 $120 \sim 150 \mathrm{gm} の$ Wistar 系雌ラットを午前 9 時から10時迄の間に断頭屠殺後, 直ちに下垂体を摘出し, 後葉を除去, 前葉を 正中線にて切半し，各々を生理的食塩水中で 3 回洗涤した。Fig. 1 亿示すように 4 個の下垂体より重複しな いように 4 halves の下垂体前葉をとり出し, test material を含む $2 \mathrm{ml}$ medium を入れた incubation flask 中に置き, ての medium を $\mathrm{O}_{2} 95 \%, \mathrm{CO}_{2} 5 \%$ の混合ガスで飽和させた後 $37^{\circ} \mathrm{C} て ゙$ incubate した. 残りの 4 個の pituitary halves を control medium 中で同様に処理をして incubate した. medium と 
Fig. 1. Method of in vitro incubation experiment

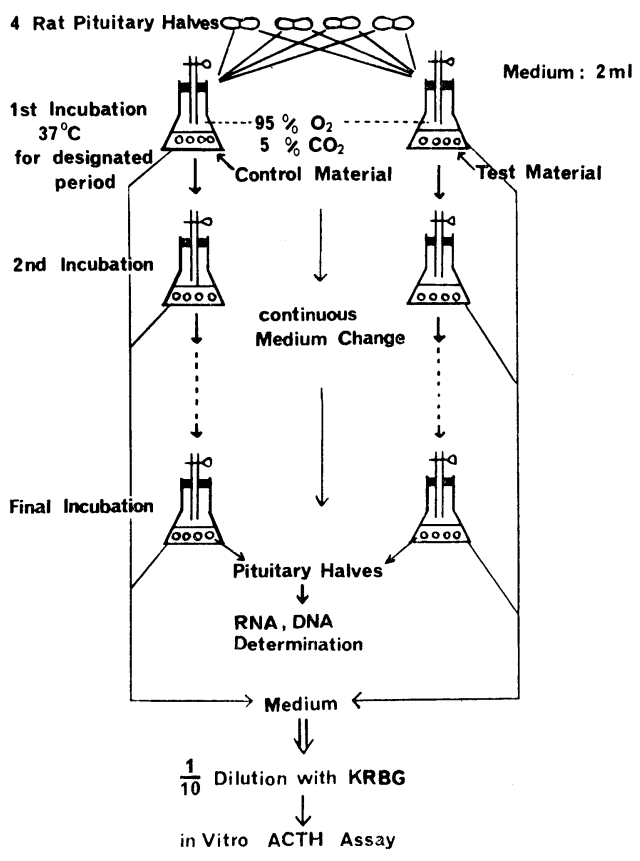

して $200 \mathrm{mg} \%$ の glucose を含有する Krebs-Ringer Bicarbonate buffer (以下 KRBG と略す) を用いた. test material としては Synthetic Lysine-8-Vasopressin(以下 L-8-V と略す) (Sandoz), Actinomycin D (以下 Act. D と略す)（日本メル ク万有), Puromycin (以下 Puro. と略す) (Nutritional Biochemicals Corporation) を KRBG で 溶解希釈して，KRBG の $2 \mathrm{ml}$ 中に L-8-V は 60 $\mathrm{mU}$, Act. D は $10 \mu \mathrm{g}$, Puro. は $50 \mu \mathrm{g}$. 含有される 様にした。なお一部の奏験では test medium とし $\tau$ glucose-free $の$ Krebs-Ringer Bicarbonate $\mathrm{Bu}$ ffer（以下 KRB と略す）を用いた。 各 medium の $\mathrm{pH}$ は7.2〜 7.4とした. 一部の実験を除き medium の交換は30分毎に $8 \sim 10$ 回施行し, 各 medium 交換前に下垂体を生理的食塩水中で 3 回洗涤 した. KRBG の medium 中で incubate した下 垂体は final incubation 後 homogenize $し$, Schmidt-Thannhauser-Schneider 法 ${ }^{16)}$ で RNA, DNA を定量した. 各 incubation 後の medium は $0.1 \mathrm{~N}$ 塩酸で $\mathrm{pH}$ を 3.0 とし, 一夜 $4{ }^{\circ} \mathrm{C}$ で放置後 first incubation 及び incubation number の偶数番目 の medium を10倍希橎して medium 中に放出さ

れた ACTH 活性を辻一安井の開発した牛副腎皮質薄片を使用する in vitro bioassay 法 ${ }^{17}$ にて測定した. 表現する単位としては $\mu \mathrm{g} / \mathrm{gm}$ を用いた。乙の意味は10倍に希釈した medium $1 \mathrm{ml}$. が牛副等皮質 $1 \mathrm{gm}$. 当り放出させるステロイド量である.

なお著者の用いた in vitro ACTH bioassay 法に対する蛋白合成阻害剂の影響をみる為に highly purified corticotrophin (Organon) を用いて上記同様の実験方式の下に，既知量の ACTH に対するてれ等 薬剤の影響を検傠した。

\section{III 実 験 成 績}

\section{〔 I ACTH assay 系に於ける効力比}

著者の用いた in vitro 法によつて medium 由に放出された AGTH 活性と standard ACTH (IIIrd International Working Standard) との間の平行性を検討した. $2 \times 2$ point assay にて測定すると Fig. 2 の如く平行性が証明され，両者の間の potency ratio は 0.00438 であつた. 以下の実験では medium の high dose 即ち10倍希釈のみ用いた。

〔II〕連続 incubation による spontaneous ACTH release に及ぼす各種薬物の影響

(1) KRBG medium に於ける spontaneous AGTH release の pattern そついて (Fig. 3)

先ず KRBG を medium として連続 incubation をした場合の下垂体前葉から medium 中に放出され た ACTH 活性とその時の各時点での下垂体前葉内の RNA/DNA 比を測定した. medium 中の ACTH 活性は No. 1 の medium では $38.66 \pm 1.55 \mu \mathrm{g} . / \mathrm{gm}$, No. 2 のedium では $28.31 \pm 1.63 \mu \mathrm{g} / \mathrm{gm}$ と低下し， No. 4 の medium では $19.24 \pm 1.05 \mu \mathrm{g} / \mathrm{gm}$ と最小となり, その後 No.6, 8, 10 の medium では各々 22.28 $\pm 1.70,24.51 \pm 2.98,22.04 \pm 2.99 \mu \mathrm{g} / \mathrm{gm}$ とほぼ一定であつた。 下垂体内 RNA/DNA 比は incubation 前は $0.77 \pm 0.06$ であつたのが， No. 1， No. 2 の incubation 後各々 $0.66 \pm 0.04,0.66 \pm 0.06$ とやや低下の傾向 
Fig. 2. Potency ratio of test medium to standard ACTH

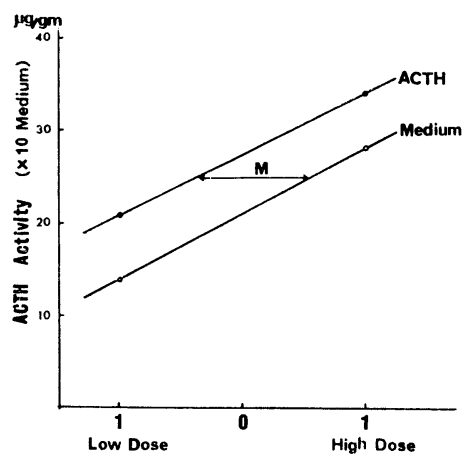

\begin{tabular}{|l|c|c||c|c|}
\hline \multirow{2}{*}{} & \multicolumn{2}{|c||}{ ACTH $(\mathrm{mU})$} & \multicolumn{2}{c|}{ Medium } \\
\cline { 2 - 5 } & $10^{-4}$ & $10^{-3}$ & $10^{-2}$ & $10^{-1}$ \\
\hline & 23.04 & 44.85 & 15.76 & 25.45 \\
& 15.76 & 31.51 & 12.50 & 26.25 \\
& 20.78 & 31.71 & 13.75 & 30.00 \\
& 24.06 & 28.41 & 13.75 & 31.25 \\
\hline Total & 83.64 & 136.51 & 55.76 & 112.95 \\
\hline Exp. No & 4 & 4 & 4 & 4 \\
\hline Mean & 20.91 & 34.13 & 13.94 & 28.24 \\
\hline
\end{tabular}

\section{Potency Ratio}

$=$ Antilog $M=0.00438$

Fig. 3. Spontaneous ACTH release from rat anterior pitutary gland in vitro \& itsRNA/DNA ratio

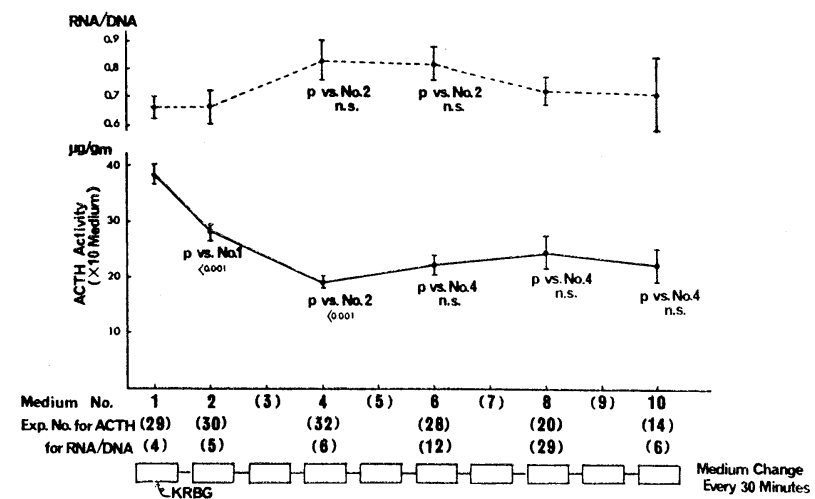

Fig. 4. Effect of glucose on ACTH release from rat anterior pituitary gland in vitro

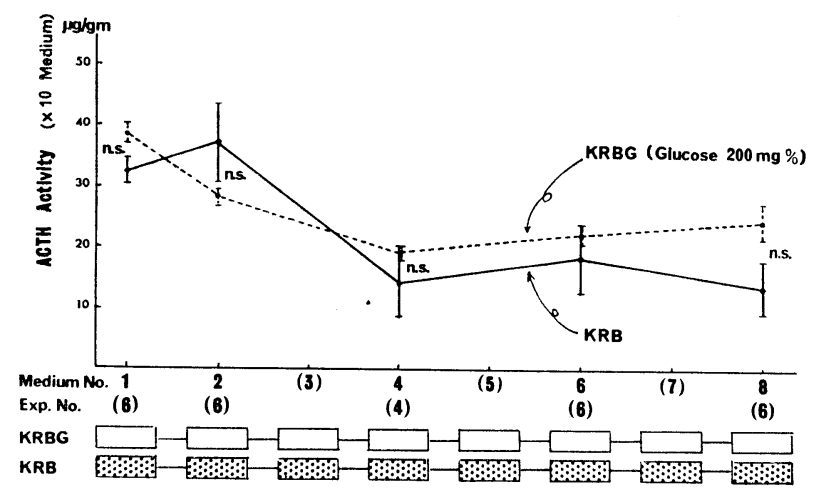

を示し, その後 No. 4 , No. 6 の incubation で各々 $0.83 \pm 0.07,0.82 \pm 0.06$ とやや増加の傾向を示し, 更 にNo. 8, No. 10の incubation 後各々 $0.72 \pm 0.05,0.71 \pm 0.13$ 前值に復した. しかしてれらの各時点で の下垂体内 RNA/DNA 比の間には有意差はなかつた。乙の事実から下垂体前葉より medium 中に放出さ 
れた AGTH 活性が減少しても下垂体内 RNA/DNA 比は前值に比し一定又はやや増加の傾向 を示し，少 なくとも減少しないととが判明した。

(2) glucose-free medium の影響について (Fig. 4)

次に glucose の spontaneous AGTH release に及ぼす影響を観察する為に glucose-free の medium (KRB) と glucose $200 \mathrm{mg} \%$ を含む medium (KRBG) そついて実験を行なつた. 下垂体前葉より KRB medium 中に放出された ACTH 活性は No. 1 medium に於ては $32.43 \pm 2.16 \mu \mathrm{g} / \mathrm{gm}$, No. 2 medium で は $37.14 \pm 6.42 \mu \mathrm{g} / \mathrm{gm}$ であつた。 その後 No. 4, No. 6, No. 8 medium では各々 $14.42 \pm 5.52,18.55 \pm$ $5.67,13.69 \pm 4.41 \mu \mathrm{g} / \mathrm{gm}$ となり KRBG medium 中に放出された ACTH 活性と比較してやや減少の傾向 を示したが，統計学的に有意差はなかつた。

(3) 蛋白合成阻害剤の影響について

ての spontaneous ACTH release のパターンに及ぽす蛋白合成阻害剤の影響を知る目的で Act. D 10 $\mu \mathrm{g} /$ flask, 又は Puro. $50 \mu \mathrm{g} /$ flask を No. 1 medium に添加して AGTH 放出のパターンを観察した. No. 2 incubation 以後は KRBG を medium として用いた. Act. D 処置群 (Fig. 5) ではNo. 1，2，4，6，8 の medium 中に放出された ACTH 活性は各々 16.44 $\pm 3.12,23.75 \pm 2.05,21.84 \pm 1.83,26.03 \pm 2.86,25.74$ $\pm 2.44 \mu \mathrm{g} / \mathrm{gm}$ であつた. 即ち無処置群と比較して No. 1 medium 中に放出される AGTH 活性は減少す るが，その後の ACTH 放出のパターンには有意差がみられなかつた. 他方, Puro. 処置群 (Fig. 6)に於ては

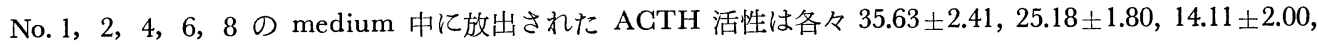

Fig. 5. Effect of actinnmycin D added in No. 1 medium on AGTH release from rat anterior pituitrary gland in vitro

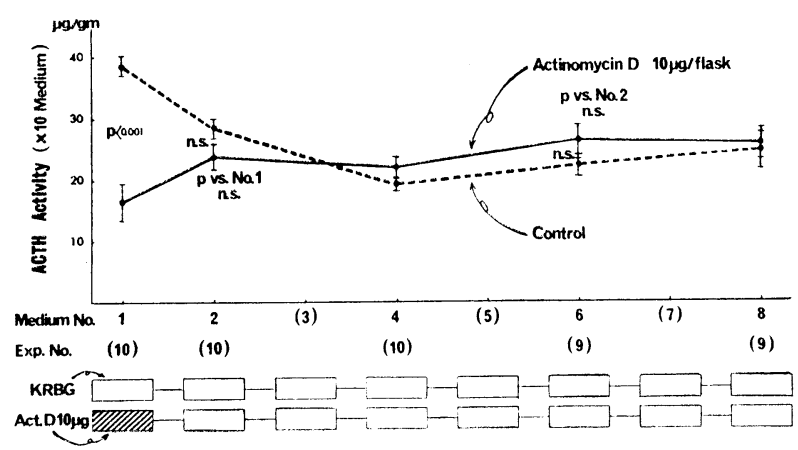

Fig. 6. Effct of Puromycin Added in No. 1 medium on ACTH release from rat anterior pituitary gland in vitro

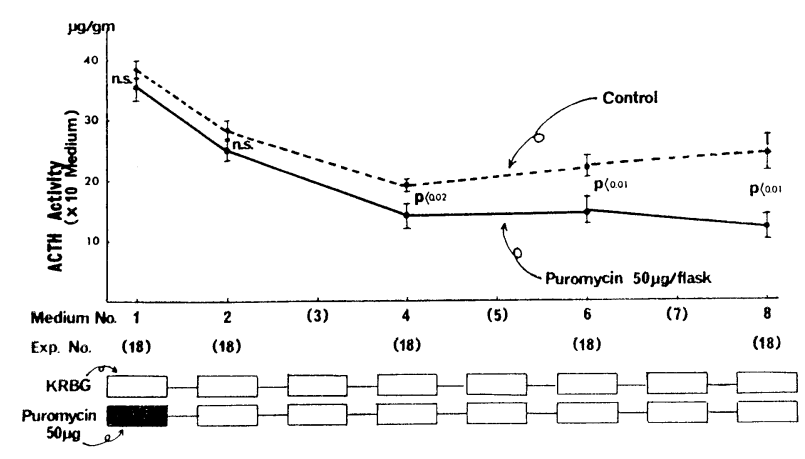


$14.91 \pm 2.12,12.22 \pm 2.05 \mu \mathrm{g} / \mathrm{gm}$ であつた. Puro. 処置群では初期には無処置群と同様な ACTH 放出パタ ーンを示すが, No. 4 incubation 以後その ACTH 放出は減少した.

なお Act. D の本実験に用いた in vitro ACTH assay 系に及ぼす影響を検討した (Fig.7)。 AGTH (highly purified corticotrophin) 及び Act. D を $2 \mathrm{ml}$ の KRBG を含む flask 中に各々 $2 \times 10^{-2} \mathrm{mU}, 10$ $\mu \mathrm{g}$ となるように溶解し， $\mathrm{O}_{2} 95 \%, \mathrm{CO}_{2} 5 \%$ を含む混合ガスで飽和後 $37^{\circ} \mathrm{C}$ で30分間 incubate した。 その 後 $0.1 \mathrm{~N}$ 塩酸で $\mathrm{pH}$ を 3.0 とし, $4{ }^{\circ} \mathrm{C}$ で一夜放置後 KRBG で10倍希釈して ACTH assay を行なつた. control としては ACTH $2 \times 10^{-2} \mathrm{mU} / \mathrm{flask}$ を用いて同様の操作をした. この assay 系に於ては ACTH は $5 \times 10^{-4} \mathrm{mU}$, Act. D は $0.5 \mu \mathrm{g}$ の環境濃度を測定したてとになる. ACTH 単独では副腎 $1 \mathrm{mg}$ 当りのス テロイド産生量は $24.49 \pm 9.29 \mu \mathrm{g} / \mathrm{gm}$ であり, AGTH + Act. では D $23.32 \pm 9.34 \mu \mathrm{g} / \mathrm{gm}$ であり, AGTH 単独に対して Act. D を添加した為に生じるステロイド産生量の増加率は $100.21 \pm 14.54 \%$ であつた. 即ち Act. D は本実験で用いた AGTH assay 系に影響を及ぼさなかつたとしてよい.

(4) L-8-V 添加の影響について

次に L-8-V 60mU/flask を添加して spontaneous ACTH release のパターンに及ぽす影響を観察した. 先ずNo. 2 の medium に L-8-V を添加した場合 (Fig. 8) medium 中に放出された AGTH 活性 はNo. 2 の medium では $45.16 \pm 2.61 \mu \mathrm{g} / \mathrm{gm}$ であり非添加群に比し有意に高く, No. 4 の medium では

Fig. 7. In vitro effect of actinomycin D on Corticoid production
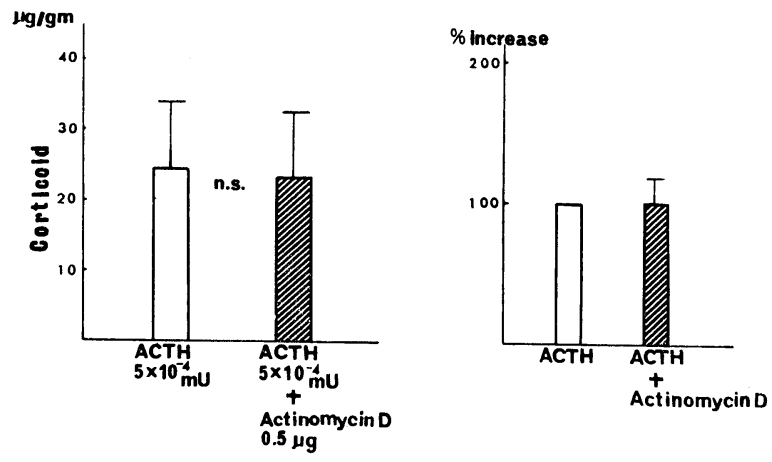

Exp. No. (4)

(4)

Fig. 8. ACTH release from rat anterior pituitary gland in vitro after addition of lysine-8-vasopressin in No. 2 medium

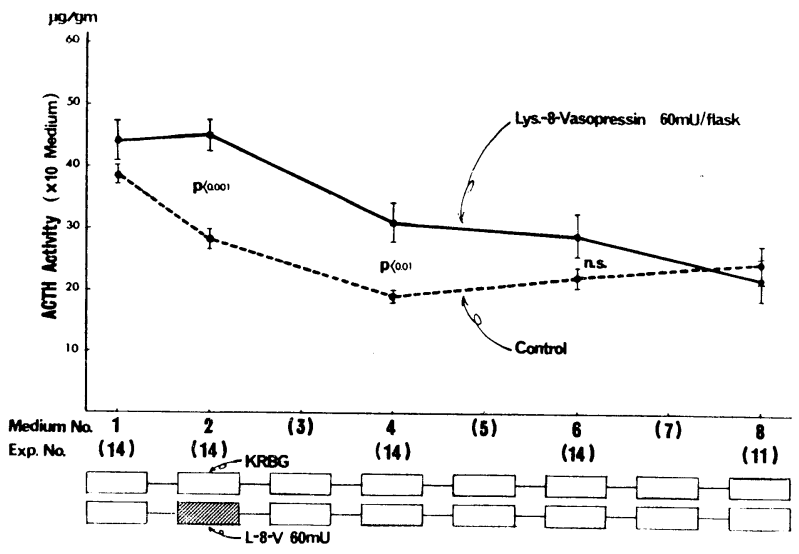

第 46 巻 第 10 号 
$31.14 \pm 3.25 \mu \mathrm{g} / \mathrm{gm}$ となり依然として有意に高い活性を示し， No. 2 medium に添加した L-8-V の影響が 1 時間後まで持続した. その後 No. 6, 8 の medium に於ては各々 $29.21 \pm 3.54,22.07 \pm 3.43 \mu \mathrm{g} / \mathrm{gm}$ であり 非添加群と同程度の活性を示しそれより低くはならなかつた.なお No. 1 medium に於ける AGTH 活性 は $44.08 \pm 3.29 \mu \mathrm{g} / \mathrm{gm}$ であり非添加群との間に有意差はなかつた。

次に L-8-V を No. 4 の medium に添加すると (Fig.9) 添加された medium 中に放出される ACTH 活性は $42.48 \pm 6.03 \mu \mathrm{g} / \mathrm{gm}$ と非添加群より有意に高くなつたが，その後の incubation に於ては各 medium 中の ACTH 活性は非添加群より低くはならなかつた. 即ちNo.6，80) medium に於ける ACTH 活性は 各々 $21.72 \pm 4.93,32.83 \pm 3.15 \mu \mathrm{g} / \mathrm{gm}$ であつた。 なお No. 1 及び 2 の medium 中の ACTH 活性は52.27士 2.95 及び $31.57 \pm 2.19 \mu \mathrm{g} / \mathrm{gm}$ であり非添加群との間に有意差はなかつた.

No. 6 medium に L-8-V を添加すると (Fig. 10) そのmedium 中の ACTH 活性は $32.95 \pm 1.99 \mu \mathrm{g} / \mathrm{gm}$ となり非添加群に比し有意に高い活性を示したが，その後の incubation に於ける ACTH 活性は No. 8, No. 10 medium で各々 $23.36 \pm 6.29,18.81 \pm 6.50 \mu \mathrm{g} / \mathrm{gm}$ であり非添加群より低くはならなかつた。 なお本 処置群の No. 1，2，4 medium 中に放出された AGTH 活性は各々 $37.31 \pm 3.77,26.63 \pm 3.04,17.56 \pm 1.80$

Fig. 9. AGTH release from rat anterior pituitary gland in vitro after addition of lysine-8-vasopressin in No. 4 medium.

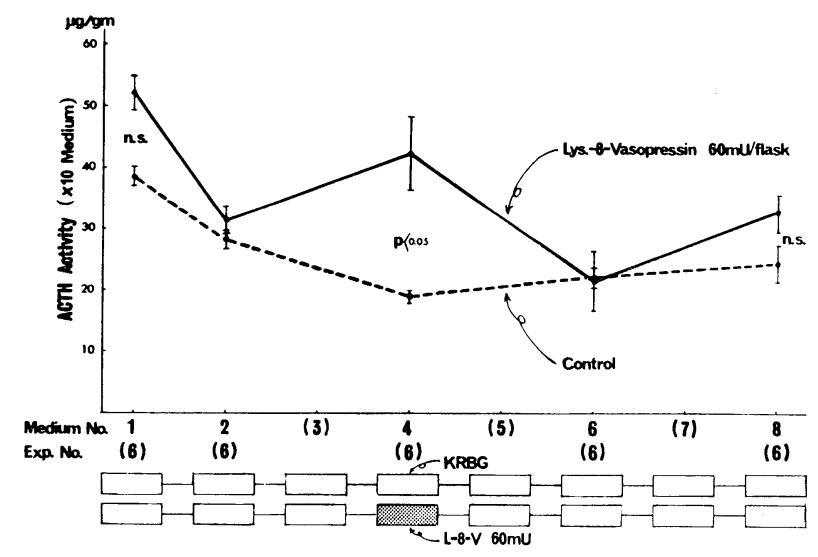

Fig. 10. ACTH release from rat anterior pituitary gland in vitro after addition of lysine-8-vasopressin in No. 6 medium

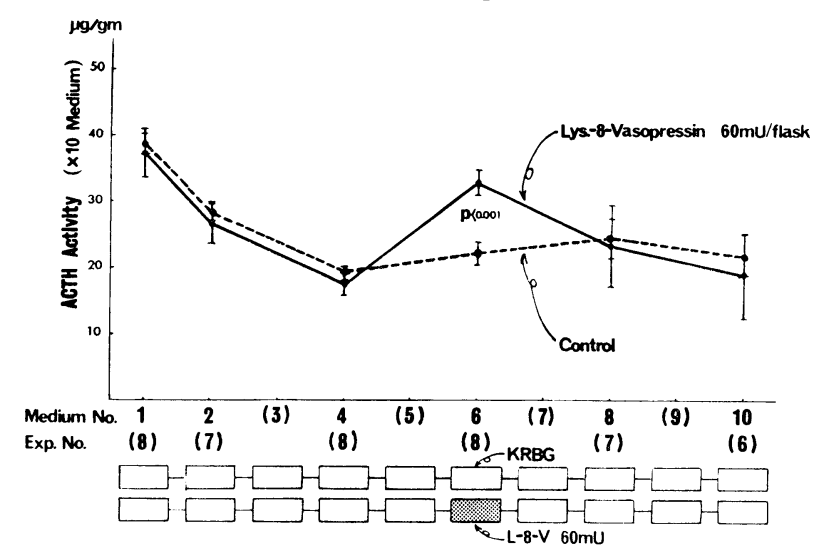


$\mu \mathrm{g} / \mathrm{gm}$ であり非添加群と同じ程度の活性を示した。

以上の実験より L-8-V 添加後の incubation に於て各 medium 中の AGTH 活性が非添加群より低く はならないととが判明した。

〔III〕 L-8-V に対する反応性

Stressor としての L-8-V 亿対する下垂体前葉の反応性を検討する目的で各種条件下で実験を試みた.

(1) preincubation の回数と反応性の関係について (Fig. 11)

Fig. 11. Effect of frequency of preincubation on responsiveness to lysine-8-vasopressin in ACTH release from rat anterior pituitary gland in vitro.

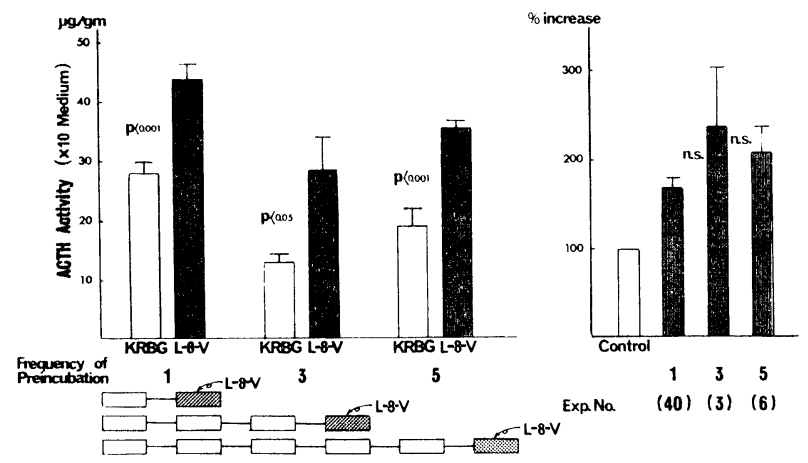

先ず L-8-V に対する反応性に及ぼす preincubation の頻度の影響を観察する為に L-8-V 60mU/flask を No. 2，4又は6の medium 亿添加した。各 medium に於ける AGTH 活性はNo. 2, 4, 6 亿於て L-8$\mathrm{V}$ 非添加群では $28.03 \pm 1.82,12.92 \pm 1.67,19.13 \pm 3.10 \mu \mathrm{g} / \mathrm{gm}$ であつたのに対して, 添加群では $43.81 \pm$ 2.59, $28.45 \pm 5.73,35.70 \pm 1.12 \mu \mathrm{g} / \mathrm{gm}$ であつた. 非添加群に対する L-8-V 添加群の medium 中に放出さ れた ACTH 活性の比は No. 2, 4, 6medium に於て各々 168.42 $\pm 9.71,237.21 \pm 66.38,208.23 \pm 27.84 \%$ で あつた. 即ち L-8-V 添加群は非添加群に比し medium 中の AGTH 活性の増加の絶対量は L-8-V を添 加する前の incubation の回数が 3 回の場合が他の場合に比べ劣るが, preincubation の頻度に関らず有意 に大きい, 又その非添加群に対する比については preincubation の回数による差異が認められなかつた.

(2) L-8-V 添加時間亡反応性の関係について (Fig. 12)

次に下垂体前葉を30分間 preincubation した後で L-8-V 添加或は非添加の際の ACTH 放出に対する incubation time の影響を観察した。 L-8-V 非添加群では incubation time が5 分間の場合 medium 中 に放出される AGTH 活性は $30.42 \pm 3.12 \mu \mathrm{g} / \mathrm{gm}$ であり，30分間及び120分間の incubation を施行した場合 各々 $28.03 \pm 1.82,34.39 \pm 4.56 \mu \mathrm{g} / \mathrm{gm}$ であり, incubation time の長短に関らず medium 中の AGTH 活 性の増加する反応には差異は認められなかつた。一方 L-8-V 添加群では 5 分間の incubation で放出され る ACTH 活性は $28.28 \pm 4.80 \mu \mathrm{g} / \mathrm{gm}$ であり非添加群との間に有意差が認められなかつたが， 30分間， 120 分間の incubation では $43.81 \pm 2.59 \mu \mathrm{g} / \mathrm{gm}, 58.23 \pm 5.88 \mu \mathrm{g} / \mathrm{gm}$ となり有意の増加を示した. L-8-V 添加群 の非添加群に対する ACTH 活性比は incubation time が5 分間, 30分間, 120分間の場合各々 $91.72 \pm$ $11.09 ， 168.42 \pm 9.71 ， 181.41 \pm 17.42 \%$ であつた. 即ち L-8-V 亿対する反応は 5 分間の incubation では 認められなく，30分間以上では120分間 incubation してもその反応性の增大はおてらなかつた。

（3） 蛋白合成阻害剤の L-8-V に対する反応性に及ぼす影響について

Act. D $10 \mu \mathrm{g} /$ flask 又は Puro. $50 \mu \mathrm{g} /$ flask の条件下で30分間 preincubation 後, その下垂体前葉を用い て L-8-V 60mU を含む $2 \mathrm{ml}$ の KRBG の medium 中で30分間 incubate し，放出された AGTH 活性 
Fig. 12. Effect of final incubation time on spontaneous and lysine-8-vasopressin-induced AGTH release in vitro.
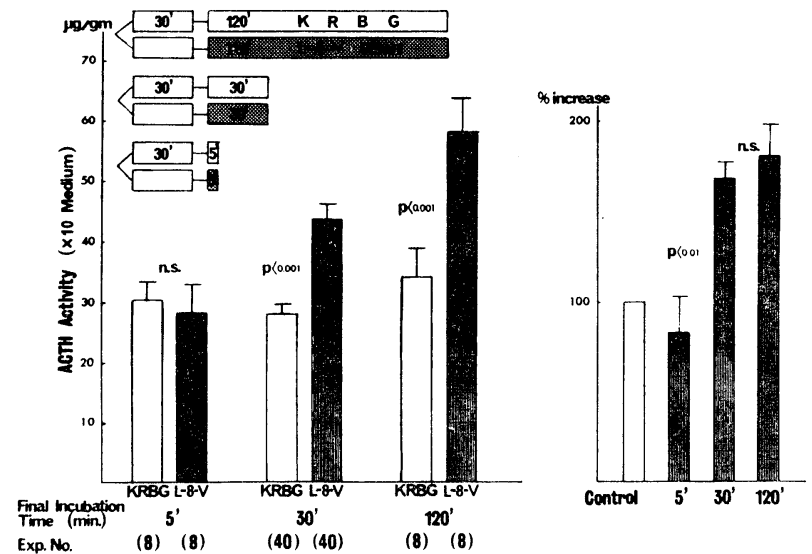

Fig. 13. Effect of pretreatment with actinomycin $\mathrm{D}$ on responsiveness to lysine-8-vasopressin in AGTH release in vitro.
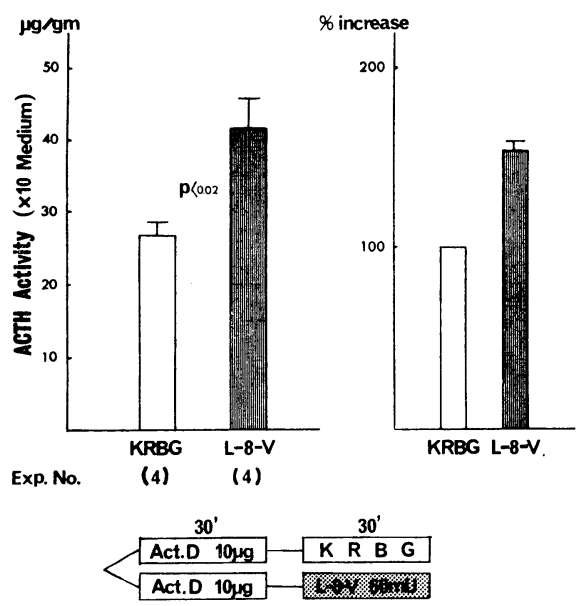

Fig. 14. Effect of pretreatment with puromycin on responsiveness to lysine-8vasopressin in ACTH release in vitro
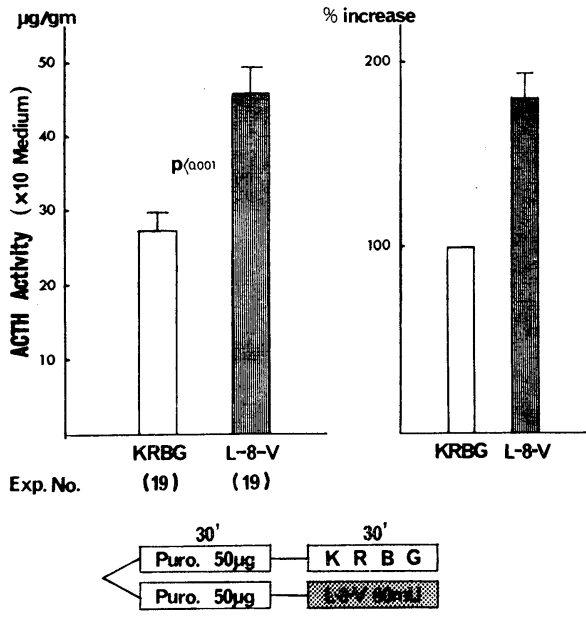

\section{を測定した.}

Act. D 前処置実験に於て (Fig. 13) medium 中の ACTH 活性は L-8-V 非添加群では $26.81 \pm 1.84 \mu \mathrm{g}$ /gm, L-8-V 添加群では $41.64 \pm 4.24 \mu \mathrm{g} / \mathrm{gm}$ であり, その非添加群に対する添加群の比は $154.41 \pm 4.78 \%$ で あつた。即ち下垂体前葉は Act. D で前処置しても十分に L-8-V に反応した.

Puro. 前処置実験に於て (Fig. 14) L-8-V 非添加群では medium 中の ACTH 活性は $27.28 \pm 2.43 \mu \mathrm{g} / \mathrm{gm}$ であつたが，L-8-V 添加群では $45.79 \pm 3.71 \mu \mathrm{g} / \mathrm{gm}$ であつた. なお後者の前者に対する比は $180.17 \pm 14.04$ \%であり，Puro. で前処置しても下垂体は十分に L-8-V に対する反応性を保持していることが判明した.

$$
\text { IV 考按 }
$$

急激な外部環境の変化が生体に加わると，下垂体より ACTH が分泌される事実に関しては多くの報告が 
ある ${ }^{1) \sim 3)}$. その際 AGTH 分泌の背景として下垂体内の合成機構か関与しているか否か, 又関与していると すればどの時点でぞのように関与しているかその詳細に関しては未解決である。外部又は内部環境の変化時

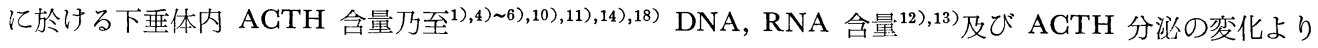
ACTH の合成をとりあげたり，アミノ酸又は核酸を放射性同位元素で標識して下垂体内の ADTH 分画 ${ }^{7) \sim ~}$ ${ }^{9)}$ 又は蛋白へ ${ }^{8), 18)}$ のりとみを観察したり，蛋白合成阻害剮で前処置後の下垂体前葉のア之ノ酸 ${ }^{18) 199}$ 乃至は 核酸星のとりてみを観察するてとにより下垂体内での ACTH の変化をとらえようとした報告がある。しか しての変化を合成というレベルだけで理解するよりも下垂体内に於ける AGTH の存在形式という面でとら えねば AGTH 分泌現象の背景にある下垂体内 AGTH の変化を理解し難く思われる。この下垂体レベルで のACTH の存在形式を検討する為には前記の如く種々の方法があるが,著者は下垂体のホルモン分泌，合成 機能をみる目的で下垂体餒置法（下垂体の in vitro incubation 法）による観察を行なつた．その方法によ れば他の内分泌腺及び神経系の影響を除外することが可能であり，直接下垂体に種々の作用物質を作用させ 得るし, 更に incubation medium 中に放出された ACTH 活性と同時に下垂体内の化学的変化を知るこ とができるので，下垂体レベルでの ACTH 分泌現象の解析が可能であるという利点がある。そして連続 incubation 法による下垂体からの spontaneous AGTH release のパターン及び各種薬物の添加によるそ のパターンの変化と, stressor としての L-8-V に対する反応性の二面からの解析を行なつた。 なお L-8-V の ACTH 放出作用の機序に関しても検討を加えた。

先ず本実験に於ては下垂体前葉を in vitro にて incubate し， medium 中に放出される AGTH 活性を 牛副腎皮質薄片を使用せる bioassay 法にて測定しているわけであるが，下垂体前葉の incubation の段階 で medium 中に確実に ACTH が放出されているととを証明するてとが必要である. Medium の10倍希 釈群， 100 倍希釈群と標準 AGTH の $0.001 \mathrm{mU}, 0.0001 \mathrm{mU}$ の間で平行性の検定を行なつた結果 Fig. 2 に 示した如く平行性が証明され，従つて著者の方法で下垂体前葉を incubation すれば medium 中に確実に AGTH が放出され得るととを知つた。 なおての平行性検定から得られた值より換算すると下垂体 $1 \mathrm{mg}$ 当 り AGTH 放出の安定した No. 8 の時点で30分間の incubation 中に $0.00048 \mathrm{mU}$ の AGTH の放出か認 められ，ての值は Fleischer 等 ${ }^{20)}$, Saffran 等 ${ }^{21}$ の值に比して極めて低值であるのは測定に供した medium が7回もの medium 交換後の 8 回目の incubation medium を用いた為であると考えられる.

〔I〕 spontaneous ACTH release について

下垂体前葉を KRBG の medium のみにて incubate した場合 medium 中に AGTH が放出される現 象を著者は spontaneous AGTH release と称した。乙れは下垂体前葉が in situ で有している metobolic condition を直接反映した現象と解される。著者の研究の焦点の一つはこの spontaneous ACTH release の連続性の有無ともし連続性が証明されればその連続性がどのような条件下で変化するかを検討すること そある.

Solomon 等 ${ }^{22}$ は同様に in vitro での TSH 放出の連続性を検討し，1時間々隔の medium 交換で少な くとも 6 回の medium 交换迄は TSH 放出か漸減しながらも認められたととを報告している.著者の観察 した AGTH 放出の連続性は30分間隔での medium 交換の条件下でNo. 4 の medium 即ち 2 時間迄は放 出量は減少するが，それ以後 No. 10 medium 即ち 5 時間迄微量ながら絶えるてとなく放出されているてと， 即ち少なくとも 5 時間迄は連続性が保証されているてとを知つた。この放出パターンの中でNo.1のそれは 断頭屠殺されたラットの in situ の下垂体前葉の反応性を反映したものであり, そのような処置が stressor として働き下垂体前葉内での放出され易い ACTH 合量が増加している状態を反映しているものと解される。 一般に内分泌腺のホルモン分泌には環境のホルモン濃度よりする feedback 的抑制が想定されており，例え ば incubation medium 中の steroid 濃度と incubate された副腎皮質の steroid 放出能との間には或る 程度の平衡関係が証明されている。乙の場合にもこの種の作業仮説を援用すれば説明に便である．即ち恐ら く medium 中に放出された ACTH の濃度と incubation 中の下垂体前葉との間に feedback regulation が作働してある程度以上の ACTH 放出は抑制されてしまうのであろうと推定され， No. 2 の incubation 
に於てなおかなりの高濃度の ACTH 放出か認められているのはNo. 1 の incubation で放出を抑制された 下垂体前葉内 ACTH が新しい ACTH-free の medium 中に於て新しい feedback 関係を形成する為と 解される. No. 4 以後 No. 10 incubation 迄の微量ながら放出されているAGTHも各 incubation に於け る下垂体前葉の状態と medium 中の AGTH 濃度の間に feedback 的な equilibration が形成される迄放 出され得ると推定されるが詳細な機序に関しては不明である.

〔 II spontaneous ACTH release のパターンと medium 内添加薬剤の関係について

生体から遊離された下垂体前葉が in vitro に於て10回もの medium 交換で合計 5 時間にわたる incubation の間微量ながら ACTH 放出が保持されているととを認めたが，ての警異的な ACTH 放出の連続 性は下垂体前葉内での代謝機転が或る程度保持されている為と考朰られる. Lee 等 $^{23}{ }^{32}$ は ${ }^{14} \mathrm{C}$-leucine の下垂 体前葉内蛋白へのとりてみが glucose-free の medium に於て著明に減少するてとを認め, 前葉組織の代 謝に於ける glucose の占める役割を高く評価している如く, medium 中の glucose が energy source と して ACTH 放出の連続性維持に重要であると考光れるのであるが, 著者の観察では対照との間に有意な ACTH 放出の減少を証明するととはできなかつた. しかし No. 4 以後の incubation に於て放出の低下の 值向を認めた。 No. 8 即ち 4 時間目の incubation ではかなりの減少が認められる点より前葉の ACTH 放 出に関する自動性保持には glucose はある程度必要と思われる. Goodner ${ }^{24)} も そ の$ 観察に於て glucose が energy source として重㚼であろうと示唆している.

一方, 前葉内の蛋白代謝がての ACTH 放出の連続性に何等かの関与をしているととが当然考えられる.

下垂体前葉からの各種ホルモン放出に対する蛋白合成阻害剂の影響に関しては諸家の報告がある，例えば， in vitro で TSH の spontaneous release 及び TRF に対する TSH の放出を Act. D も Cycloheximide も抑制しないし ${ }^{25)}$, in vivo でも同様の報告がある ${ }^{26)}$. 其の他にも in vitro で LH の放出及び LH-RF

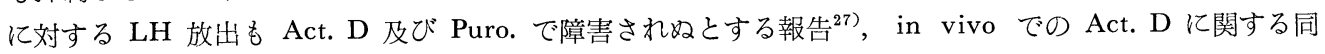
様の報告 ${ }^{28)}$ ，FSH の放出は in vitro で Act. D 及び Puro. によつても障害されないが， hypothalamic extract に対する FSH 放出は両者によつて抑制されるとする報告 ${ }^{29)}$ があり， GH-RF に対する GH 放出

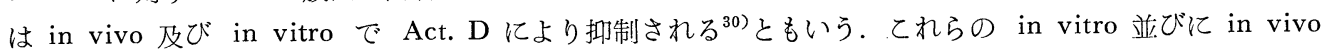
に於ける蛋白合成阻害剤の各種下垂体前葉ホルモン分泌汶する影響に関してあるホルモンは抑制され，あ るホルモンは抑制されないという奇妙な解離が何に起因するのが問題であるが，ACTH 放出の in vitro での観察に於ける蛋白合成阻害剤の影響に関しては未だ報告が少ない. 先ず著者の興味は前項で観察し得た in vitroに於ける spontaneous AGTH release の連続性に対して蛋白合成阻害剤の添加がどのような影響 を与え得るかにある。添加された蛋白合成阻害戍が ACTH の分泌に至る迄のどの部分に作用するか不明で あり, 又 ACTH の分泌に至る迄の過程にのみ特異的であるとは結論できないのであるが, Act. D と Puro. の作用部位の差異を考慮に入れてその影響を観察した.

DNA dependent RNA synthesis の阻害剂といわれる Act. $\mathrm{D}^{31332)}$ を No. 1 medium 亿添加した処, そ の medium 中への ACTH 放出が減少しその後の ACTH 放出のパターンには非添加群と比べ変化がな かつた. Act. D は in vitro 亿於て60分間 incubate して ${ }^{3} \mathrm{H}$-uridine の核酸へのとりてみを $10 \mu \mathrm{g} / \mathrm{ml}$, $1 \mu \mathrm{g} / \mathrm{ml}$ で各々 $98 \%$ ，86\%抑制し， ${ }^{3} \mathrm{H}-$ leucine の蛋白へのとりてみを $10 \mu \mathrm{g} / \mathrm{ml}$ では39\%しか抑制しなく, $1 \mu \mathrm{g} / \mathrm{ml}$ では抑制がみられないといわれている ${ }^{25)}$. 又 $0.5 \mu \mathrm{g} / \mathrm{ml}$ の Act. D が ${ }^{3} \mathrm{H}$-uridine 及び ${ }^{14} \mathrm{C}-$ leucine のとりとみを $83 \%$ 及び $23 \%$ 抑制したとの報告もある ${ }^{19)}$. in vovo でラットに体重 $100 \mathrm{gm}$ 当り $100 \mu \mathrm{g}$ の Act. $\mathrm{D}$ を投与すると20時間後にも ${ }^{3} \mathrm{H}$-uridine のとりてみの抑制がみられ28), in vitro で $20 \mu \mathrm{g} / \mathrm{ml}$ で 6 時間後 に75\%の抑制が報告されている ${ }^{29}$. 著者の央験結果即ち Act. D 添加時にはその medium 中の ACTH 活 性が著明に低いが，その影響はN No. 2 incubation 以後では殆んぞないという現象に関して次のととが考学 られる。第一は Act. D そよる ACTH 放出の抑制, 第二に放出された ACTH の Act. D による不活化, 第三は用いた ACTH assay 系への抑制等が考えられ, Arimura 等 ${ }^{199}$ は in vitro の実験より Act. D が下 垂体内の ACTH の readily releasable pool を減少させるのではないかとも言つているが, 著者の実験モ 
デルではこの考学を肯定し難い. 即ち下垂体内の AGTH の readily releasable pool が Act. D によつ て娍少させられるというととはその AGTH が medium 中へ放出されたということであるが，著者の No. 1 medium 中ではむしろ AGTH 活性が極めて低值であつた. 又 No. 1 incubation に於てそのよう な現象が起てれば，No. 2 incubation に於てもその影響が現れ，ACTH 放出が減少する筈であるが，奏 験結果ではそれは認められなかつた。 又 medium をそのまま希哷して in vitro の ACTH assay 系に供 するという著者の実験モデルでは medium 中の Act. D が副篎皮質レベルで ACTH 作用を抑制する可能 性が存在するが，てれは Fig.7 で示した予備実験で否定され，Ferguson 等33)もその in vitro の実験で否 定している. 又との Fig.7 の実験結果より ACTH の不活化も否定される. 以上の考察から従つて, Act. D は下垂体前葉からの spontaneous ACTH release を抑制するのではないかと考元られる。 そして 現象的には No. 1 medium に添加された Act. D の影響は No. 2 incubation 以後に及ぶことなく No. 8 incubation に至る迄 spontaneous AGTH release のパターンは Act. D によつて影響されない.

Act. D の作用時間が30分間という短い時間であつたととを考慮に入れる必要はあるが，少なくとも Act. $\mathrm{D}$ では孵置下垂体前葉の連続的な $\mathrm{ACTH}$ 放出は抑制されないととを知つた。

てれに対して sRNA からアミノ酸の合成を妨げ34)，更には AGTH 合成をも抑制するといわれる Puro. の影響について観察すると, No. 1 medium 亿添加後 No. 2 incubation 迄は非添加群との間に差異はな いが, No. 4 incnbation 即ち 3 回の medium 交換後の medium 中への ACTH 放出に减少が認められ, No. 8 incubation に於ては殆ど medium 中に AGTH 活性が認められなくなつているととを知つた。 即 ち spontaneous AGTH release の連続性は Puro.によつて阻害された.

Watanabe 等 ${ }^{29}$ は下垂体前葉を 6 時間 incubate し， Puro. $20 \mu \mathrm{g} / \mathrm{ml}$ による ${ }^{14} \mathrm{C}-$ ア 酸の蛋白へのと りてみが9.3\%抑制されるてとを報告しているが，てのアミノ酸の蛋白へのとりてみを抑制する Puro. と uridine の RNA へのとりとみを抑制するといわれる Act. D とを同じように No. 1 medium へ添加し， 30分間それら蛋白合成阻害剂と接触させられた下垂体前葉がその後の spontaneous AGTH release に於て 根異した反応パターンを示したことは興味あるととである。それは spontaneous release を来たし得る ACTH の下垂体内での動員様式に関して示唆を提供するからである.

この下垂体前葉内での直ちに放出可能な ACTH のプール即ち AGTH の readily releasable pool の想 定と spontaneous AGTH release の連続性の背景とを考察する場合, ある種の stressor を用いて readily releasable pool の変動を強制した後の spontaneous AGTH release を観察するととが必要と思われる. Fig. 8, Fig. 9, Fig.10 は in vitro での stressor として L-8-V を用いてその観察を行なつた結果である. L-8-V の ACTH 放出現象の作用部位に関しては論が多いとてろであり, 視床下部に作用して GRF を動 員させるという立場 ${ }^{36)}$, 或は CRF 分泌神経細胞の axon が下垂体門脈の開口部に作用する可能性を唱元 ている立場 77 )等があり混乱しているが, 著者等の研究グループの一連の in vivo ${ }^{23,3), 38)}$, in vitro ${ }^{38), 39}$ の観察 では L-8-V はむしろ下垂体前葉への直接作用が大であるよう亿考光られる。in vivo 於ては40),41)ともか く, in vitro 亿於て下垂体前葉への直接作用を支持する報告は多い45). 乙の L-8-V を No. 2 medium 亿 添加し ACTH 放出を強制させられた下垂体前葉は No. 4 incubation に於て AGTH 放出が消失する可 能性があると想定されたが，実際には非添加群に比して高濃度の ACTH を放出しているととが観察され， No. 6, No. 8 incubation 亿至る迄 AGTH 放出が維持されているととを知つた. 又 No. 4 medium 亿添 加した場合も, No. 6 medium に添加した場合も前者では No. 8 incubation, 後者では No. 10 incubation 迄明らかに AGTH 放出が持続している.

下垂体内或は体液中の ACTH の存在形式に関しては実験的試みと speculative な展望とが数多く報告 されている. 即ち Dasgupta 等は1958年牛の下垂体粗抽出物を酸処理又は尿素処理すると Sayers test で 活性を示すととを見出し，てれを corticotrophin の precursor という意味で precorticotrophin と名付け た ${ }^{42)}$. そして下垂体内の全 corticotrophic activity の少なくとも80\%はての precorticotrophin の形で存 在していると報告している ${ }^{43}$. 又 Currie 等は ACTH はヒ卜下垂体内で 2.5\% TCA で抽出可能な low 
molecular weight component と protein 又は protein-bound component の二型に分けられて存在し， 前者は全 ACTH 活性の約30\%であると述べている ${ }^{44)}$.

著者は本実験，即ち spontaneous AGTH release 並びにその放出パターンに及ぼす Act. D, Puro., L8-V 添加の影響加万垂体内の ACTH プールに関して次の想定を行なつた. 即ち下垂体内に於て ACTH は readily releasable pool ${ }^{19)}$ とその前段階の inactive AGTH pool の型で存在するのではないかと想定 した. Puro. はこの両プールの前段階の蛋白合成を障害すると考えられ，Puro. そより No. 4 incnbation 以後で spontaneous ACTH release が障害されるととからこの両プールの ACTH 放出予備能は 1 時間半 以下という小さいものと考えられる. 又 medium 中に stressor として L-8-V が添加されると medium と下垂体前葉との間の新しい homeostasis が形成される迄 medium 中への ACTH 放出が持続するが, その完成と共に ACTH 放出は終止し，下垂体前葉内での ACTH の readily releasable pool もそれ従 つて新しい equilibration に入るものと想定される.

〔III) in vitro に於ける L-8-V の ACTH 放出作用について

Fig. 11 亿示した如く preincubation の回数の差異に関らず下垂体は L-8-V に対して十分な反応性を有 していて, その L-8-V 添加群の非添加群に対する ACTH 放出の増加量は preincubation が $1,3,5$ 回 の時各々 $15.78,15.53,16.57 \mu \mathrm{g} / \mathrm{gm}$ と略等しかつた. 下垂体は同じ強さの stress に対してはその preincubation の頻度の差異という条件付け，即ち L-8-V による stress 前の readily releasable pool の大きさ に関らず殆ど同じ大きさの反応を示している。それが十分に可能な readily releasable pool を有するとの 考え方からすれば下垂体はこのような反応の巾を十分にもつているものとせねばならない.

更に spontaneous AGTH release は5 分間の incubation で十分起とるととが証明されたが， incubation 時間を延長しても ACTH 放出の増加が認められないことは medium 中の ACTH と readily releasable pool の ACTH の間に平衡関係が成立する為と解される. 又 L-8-V に対する反応の出現には 5 分 以上要した. この lag time 及び Fig. 11 で示された如く readily releasable pool のまだ十分残存してい ると考えられる No. 2 incubation と，そのプールが最も減少して inactive ACTH pool からの交換によ つてその補充を行ない初めて AGTH を放出していると思われる No. 4 incubation とに於て略等しい量 の ACTH 放出が認められることは L-8-V が細胞膜にのみ作用してその透過性を元進して大量の ACTH を放出していると考えるよりも， inactive AGTH pool から readily releasable pool への変換を促進して そのために十分に大量の AGTH を放出できる程の readily releasable pool を形成している，又はその両 者であると考えた方が妥当である.

著者の未発表の成績では L-8-V 添加後15分間の incubation で30分間の場合と略等しい量の ACTH 放 出を示した. この時間的関係は老籷 ${ }^{2)}$ の報告している種々の stress の下で GRF が発動されて plasma ACTH の上昇するまでの時間に略一致している. このととより CRF の ACTH 放出作用は inactive ACTH pool から readily releasable pool への変換を促進し，一部は細胞膜の透過性を元進するととにあ ると推論するのが罗当であろう.

L-8-V 添加の非添加に対する ACTH 放出の増加量は30分間の incubation では $15.78 \mu \mathrm{g} / \mathrm{gm}$ であり, 120分間の場合は $23.84 \mu \mathrm{g} / \mathrm{gm}$ であり統計学的に有意差を認めた. これは L-8-V の作用時間の差異による ものであろう. しかし更に長時間の incubation を施行するなら, inactive ACTH pool は比較的小さいか ら L-8-V による ACTH 放出の増加量は時間と共に減少し, 遂には一定となるであろうと考えられる。

前述のような急激な刺激下に於ける ACTH 放出と下垂体内の蛋白合成との関係は興味深い問題である. Vernikos-Danellis $^{1)}$ は stress 後の下垂体の ACTH 放出能力は新 ACTH の合成能力に依存するらしいと 述べている. 著者は先に L-8-V の作用部位を想定したが，もしての L-8-V が蛋白合成レベル以下に作用 するか, 又はその作用が少なくとも蛋白合成に無関係であるならば，in vitro に於て蛋白合成阻害剤で前 処置後の下垂体に stressor として L-8-V ${ }^{39) \sim 41)}$ を作用させても十分反応する筈である. 著者の実験では下 垂体は絶対量に於ても又 L-8-V 非添加群に対する比に於ても L-8-V 添加により ACTH 放出を十分に引 
起す成績を得た。乙の反応性はPuro.で120分間前処置した後でも同様であつた。（未発表）。乙の事実は L-8-V の作用部位が蛋白合成レベル以下又は少なくとも L-8-V の ACTH 放出作用が蛋白合成に無関係で あるととを証明するものであり，且又急激な刺激下で蛋白合成，更には ACTH 合成よりも先ず AGTH の 放出が起こるととを意味している. 同様のてとが in vivo 亿於て Estep 等 ${ }^{18)}$ によ報告されている. 以上 の L-8-V に対する下垂体の反応性と preincubation の回数, L-8-V の添加時間及び蛋白合成阻害剈との 関係より下垂体は急激な刺激に対する十分な ACTH 放出予備能を保持し,その際蛋白の合成よりも ACTH の放出が一次的に起とると解された，又その stressor の一つである L-8-V は inactive AGTH pool から readily releasable pool への変換の促進，又はそれと同時に細胞膜の透過性の元進により下垂体から大量 の ACTH を放出させ，乙れは蛋白合成とは無関係であろうと推察された。なお CRF の ACTH 放出作 用も L-8-V に於けると同様であると推論された。

\section{$\mathrm{V}$ 結 論}

in vitro 連続 incubation 法を用い, 下垂体前葉組織片からの spontaneous ACTH release のパターン 及び各種薬物のそのパターンに及ぽす影響と stressor としての L-8-V に対する下垂体前葉組織片の反応性 の二面からの解析を行ない, 次の結論を得た.

(I) spontaneous AGTH release について

(i) 下垂体前葉を KRBG の medium のみにて incubate した場合, medium 中に ACTH が放出さ れる現象を spontaneous ACTH release と称した。

(ii) 下垂体前葉からの spontaneous AGTH release は2 時間目迄は徐々に減少し, その後 5 時間目迄微 量ながらその放出の連続性を認めた。 その間を通じ下垂体前葉内 RNA/DNA は略一定であつた.

〔II〕 spontaneous AGTH release に及ぼす medium 内添加薬剤の影響について

(i) glucose-free の medium (KRB) でも $200 \mathrm{mg} \% の$ glucose を含む medium (KRBG) と同様の ACTH 放出のパターンを示した.

(ii) 最初の incubation medium 飞 Act. D を添加した場合, その時のみ ACTH 放出の減少があつた が，その後の spontaneous ACTH release は障害されなかつた.

(iii) Puro. を最初の incubation medium 飞添加した場合は 2 時間目以後 AGTH 放出の減少が認めら れた.

(iv) L-8-V を incubation 後 1,2 又は 3 時間目の medium に添加すると, 各々の場合下゙垂体前葉は十 分な反応を示し, 略等しい量の AGTH を放出し, その後の spontaneous ACTH release は L-8-V 非添 加群と比較して減少を示さなかつた.

(V) 以上の実験結果より，下垂体前葉内に於て ACTH は readily releasable pool とその前段階の inactive ACTH pool の型で存在し，その pool は著者の in vitro に於ける実験では約 1 時間半の AGTH 放出予備能を有すると推察された．そしてL-8-V添加により medium と下垂体前葉との間の平衡が破れ， ACTH 放出が起とり, readily releasable pool の減少が inactive ACTH pool からの動員を誘発し， こ うして順次 ACTH 生成系の変動を起てす. medium と readily releasable pool との間の新しい平衡の 成立と共にての一連の系も徐々に平衡関係を樹立し, ACTH の生成, 放出反応が一定となると解された。

(III) in vitro に於ける L-8-V の ACTH 放出作用について

(i) preincubation の頻度に関係なく下垂体は L-8-V に対して十分反応性を有した.

(ii) spontaneous ACTH release は5 分間で認められ, その後 inbubation 時間を120分迄延長しても変 化はなかつた. L-8-V 亿対する下垂体の反応は 5 分間の incubation では認められなかつた. 30分間の incubation で認められ，120分間の incubation では一首 AGTH の放出が増加した.

(iii) 蛋白合成阻害剂で前処置後の下垂体の L-8-V 亿対する反応性は十分に認められた.

(ii) 以上の実験結果より, L-8-V は inactive ACTH pool から readily releasable pool への変換を促 
進し，後者の pool の増大をもたらし ACTH 放出を来たすが，一部には細胞膜の透過性も六進すると考光 られ，乙れらは蛋白合成とは無関係であろうと推察された。なお CRF の AGTH 放出作用もこれと同様 であると推論された。更に急激な刺激下では下垂体内の蛋白合成更には ACTH 合成よりも先ず AGTHの 放出が起とると想定された.

尚本論文の要旨は第 42 回日本内分必学会総会に於て発表した.

稿を終るに臨み，終始御㤅篤なる御指導，御校閲を睗わりました恩師辻昇三教授に深甚なる謝意を表しま す。研究の当初より種々御指導, 御教示を戴きました安井博和博士に深謝致しますと共に実験に当り御協 力戴いた教室 ACTH 研究グループの諸先生方に心から感謝致します.

\section{文献}

1) Vernikos-Danellis, J. : Endocrinology, $72: 574$, (1963).

2) Oimomi, M. : Folia Endocr. Jap., 44 : 1056, (1968). 3) Kohzuki, Y. : Folia Endocr. Jap., 45 : 939, (1969). Gemzell, C.A., D.C. Van Dyke, C.A. Tobias and H.M. Evans : Endocrinology, $49: 325$, (1951) 5) Sydnor, K.L. and G.Sayers : Endocrinology, $55: 621$, (1954).

6) Fortier, C. : Proc. Soc. Exp. Biol. Med., 100 : 13, (1959). 7) Jacobowitz, D., B.H. Marks and J. Vernikos-Danellis : Endocrinology, $72:$ 592, (1963). $\quad$ 8) Wool, I.G., R. Scharff and N. Mages : Amer. J. Physiol., $201: 547,(1961)$.

9) JACOBOWITZ, D., B.H. Marks and J. Vernikos-Danellis : Fed. Proc., $22: 507,(1963)$. Med., $100: 763$, (1959). 10) Hess M., J.J. Corrigan, Jr. and J.A. Hodack : Proc. Soc. Exp. Biol. Biol. Med., 106 : 420, (1961). 11) Hess, M., J.J. Gorrigan, Jr. and J.A. Honack : Proc. Soc. Exp. 12) Kraicer, J. and S.C. Cheng : Amer. J. Physiol., $214: 158$, (1968). 13) Kraicer, J., M. Herlant and F. Duclos : Canad. J. Physiol. Pharmacol., 45 : 947, (1967). 14) Ducommun, P., S. Ducommun, M. Jobin, M. Jobin, J. Kraicer, P. Mialhe, C. Mialhe-Voloss and C. Fortier : Schweiz.Med. Wschr., 94 : 892, (1964). 15) Yasui, H., M. Cimomi, I. Kohzuki, H. Taniguchi, M. Higashi, S. Itoh and S. Tsuji : Folia Endocr. Jap., 44 : 754, (1968). 16) Schneider, W.C. : J. Biol. Chem., $164: 747$, (1946). 17) Yasui, H. : Folia Endocr. Jap., $41: 643$, (1965). 18) Estep, H., P.F. Mullinax, R. Brown, K. Blaylock and E. Butts : Endocrinology, $80: 719$, (1967). 19) Arimura, A., C.Y. Bowers, A.V. Schally, M. Saito and M.C. Miller III : Endocrinology, $85: 300$, (1969). $\quad 20)$ Fleischer, N. and W. Vale : Endocrinology, $83: 1232$, (1968). $\quad 21)$ Saffran, M. and A.V. Schally : Canad. J. Bochem. Physiol., $33: 408$, (1955). $\quad 22$ ) Solomon, S. H. and J.M. McKenzie : Endocrinology, $78: 699$, (1966). 23) Lee, K.L., C.Y. Bowers and O. Neail Miller : Endocrinology, $83: 754$, (1968) 24) Goodner, G.J. : Endocrinology, $75: 846$, (1964). $\quad 25)$ Vale, W., R. Burgus and R. Guillemin : Neuroendocrinology, $3: 34$, (1968).

26) Bowers, C.Y., K. Lee and A.V. Schally: Endocrinology, $82: 303$, (1968). $\quad$ 27) Crighton, D.B., S. Watanabe, A.P.S. Dhariwal and S.M. McCann : Proc. Soc. Exp. Biol. Med., $128: 537$, (1968). 28) Schally, A.V., C.Y. Bowers, W.H. Carter, A. Arimura, T.W. Redding and M. Saito : Endocrinology, $85: 290$, (1969). 29) Watanabe, S., A.P.S. Dhariwal and S.M. McCann : Endocrinology, $82: 674$, (1968). Schally, A.V., E.E. Muller and S. Sawano : Endocrinology, 82 : 271, (1968).

31) Samuels, L.D. : New. Eng. J. Med., 271 : 1301, (1964). 32) Hurwitz, J., J.J. Furth, M. Malamy and M. Alexander : Proc. Nat. Acad. Sci. U.S.A., 48 : 1222, (1962).

33) Ferguson, Jr., J.J. and Y. Morita : Biochim. Biophys. Acta, $87: 348$, (1964).

34) Nathans, D. : Fed. Proc., $23: 984$, (1964). 35) Adiga, P.R., I. Uemura and T. Winnick : Biochemistry Wash., $4: 246$, (1965) 
36) Hedge, G.A., M.B. Yates, R. Marcus and F.E. Yates : Endocrinology, 79 : 328, (1966). 37) Hedge, G.A. and P.G. Smelik : Neuroendorinology, 4 : 242, (1969). 38) Yasui, H. : J. Jap. Med. Ass., 60 : 552, (1968). 39) Nakai, Y. : Folia Endocr. Jap., 43 : 957, (1967). Grindeland, R.E., F.E. Wherry and E. Anderson : Proc. Soc. Exp. Biol. Med., $110: 377$, (1962) 41) Gwinup, G., T. Steinberg, G.G. King and J. Vernikos-Danellis : J. Clin. Endocr., 27 : 927, (1967) 42) Dasgupta, F.R., and F.G. Young : Nature, 182 : 32, (1958). 43) Dasgupta, P.R., S.A. Margolis and R.I. Dorfman : Acta Endocr., 55 : 31, (1967). 44) Currie, A.R. and B.M.A. Davies : Acta Endocr., 42 : 69, (1963). 45) Ando, S., L.B. Guze and E.M. Gold : Endocrinology, $74:$ 894, (1964). 